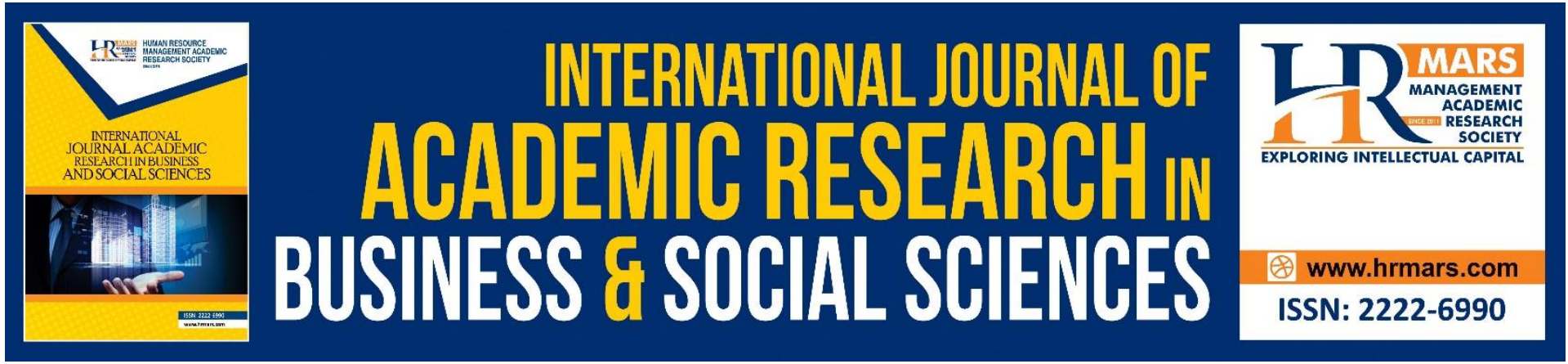

\title{
The Implementation of Social Media Marketing Strategies to Increase Brand Awareness and Engagement Behaviour of a Private College
}

Khairul Nisa Hairuddin, Thoo Ai Chin, Huam Hon Tat and Hang See Pheng

To Link this Article: http://dx.doi.org/10.6007/IJARBSS/v11-i7/10468

DOI:10.6007/IJARBSS/v11-i7/10468

Received: 28 May 2021, Revised: 30 June 2021, Accepted: 18 July 2021

Published Online: 29 July 2021

In-Text Citation: (Hairuddin et al., 2021)

To Cite this Article: Hairuddin, K. N., Ai Chin, T. , HUam, H. T., \& Hag, S. P. (2021). The Implementation of Social Media Marketing Strategies to Increase Brand Awareness and Engagement Behaviour of a Private College. International Journal of Academic Research in Business and Social Sciences, 11(7), 1492-1507.

Copyright: (c) 2021 The Author(s)

Published by Human Resource Management Academic Research Society (www.hrmars.com)

This article is published under the Creative Commons Attribution (CC BY 4.0) license. Anyone may reproduce, distribute, translate and create derivative works of this article (for both commercial and non-commercial purposes), subject to full attribution to the original publication and authors. The full terms of this license may be seen

at: http://creativecommons.org/licences/by/4.0/legalcode

Vol. 11, No. 7, 2021, Pg. 1492 - 1507

Full Terms \& Conditions of access and use can be found at http://hrmars.com/index.php/pages/detail/publication-ethics 


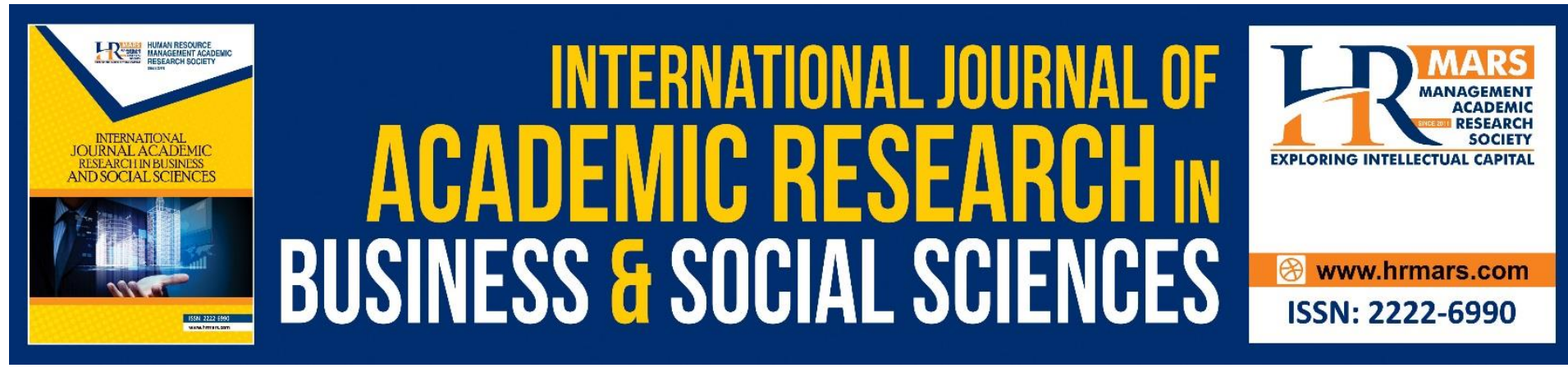

\title{
The Implementation of Social Media Marketing Strategies to Increase Brand Awareness and Engagement Behaviour of a Private College
}

\author{
Khairul Nisa Hairuddin ${ }^{1}$, Thoo Ai Chin ${ }^{2}$, Huam Hon Tat ${ }^{3}$ and \\ Hang See Pheng ${ }^{4}$ \\ ${ }^{1,2}$ Azman Hashim International Business School, Universiti Teknologi Malaysia, Johor, \\ Malaysia, ${ }^{3}$ Putra Business School, Universiti Putra Malaysia, Selangor, Malaysia, \\ ${ }^{4}$ Department of Mathematical Sciences, Faculty of Science, Universiti Teknologi Malaysia, \\ Johor, Malaysia \\ Email: khairulnisahairuddinn@gmail.com, acthoo@utm.my, huam@putrabs.edu.my, \\ sphang@utm.my
}

\begin{abstract}
The study was conducted in Malaysia and a private college was chosen as the case study. The method used for this study was action research where a problem is diagnosed from a problematic situation and from the problem, an intervention needs to be implemented to solve or improve the problem. The intervention chosen for this study was to implement social media marketing strategies for a college's Instagram account. In this study, qualitative and quantitative research design were used including interview and survey distribution. This study consisted of two cycles of interventions. To measure the effectiveness of the intervention for both cycles, the data from Instagram insights were analysed and compared before and after the implementation. The findings show that the major problem faced by the private college is brand awareness. The survey also indicated that the college has low Instagram engagement behaviour. After the implementation, there were positive changes in the performance of the social media especially the number of profile visits and the followers' growth. The engagement behaviour of the college Instagram was also improved. The implementation of social media marketing in this study had improved the college's Instagram performance and its brand awareness as there are hundreds of people visited the Instagram profile as well as followed the account.
\end{abstract}

Keywords: Brand Awareness, Digital Marketing, Social Media Marketing, Advertising and Promotion, Engagement Behaviour

\section{Introduction}

\section{Background of the Company}

The private college chosen is a community college that provides foundation and diploma certificates for all the leavers of Malaysian Certificate of Education in Malaysia. The college was established in late 2017 and located in Selangor. The private college is officially appointed by one of the prominent universities in Malaysia as a smart partner to provide and hold classes 
for courses which are certified by University and the Minister of Higher Education. Since the year of its establishment, the college already has 200 students enrolled in the programs offered. There are three types of programs offered in this college which are Certificate of Completion (short courses), Professional and Executive Certificate (foundation), and Professional and Executive Diploma.

There are five short courses offered which are Basic English Application, Self-Image Development, Sales and Marketing, Fundamental of Logistics, and Hospitality Operations. The foundation programs offered are Logistics Operations, Hospitality Operation and Sales and Marketing. For the diploma programs, the offered programs are logistics Operation Management, Hospitality Operations Management, and Sales and Marketing. All the certificates of the programs enrolled are issued by a well-recognized university in Malaysia.

The founder of the college believed that choosing the right educator is important to ensure that students have proper skills and knowledge for their career path journey. The college's mission is to lead all the students to reach the highest standards of professionalism during their course of study at the same time enjoy the study journey to the fullest. The college offers programs to those who may not have the opportunities to pursue their studies in conventional academic programs. All the programs are designed to enhance the skills and knowledge related to industry-specific issues. To provide the best for the students and achieve its mission, the college selected the modules carefully and all the modules are thoroughly developed by academicians, professionals and experts related to a particular subject.

\section{Problem Identification}

The college has many industrial partners and all the industrial partners are helping the students to experience the real-world working environment from their companies. This private college is offering a variety of professional programs for those who want to enhance their skills and knowledge in a specific field. Unfortunately, due to lack of advertising and promotions, the college is hardly known by the public and its unique selling are invisible in the education sector.

In Malaysia, community colleges have been existed since 2003. The formal and non-formal programs offered at community college are the mixed of $75 \%$ practical and $25 \%$ theoretical. Over the years, the enrolment into these community colleges are declining due to the varieties of public and private universities. Moreover, to enter public universities, students are given more advantages in terms of scholarships and study loans. Even though the study fee to enter a community college is cheaper than public and private universities, but apparently, community colleges do not provide scholarships or loans, therefore, students tend to choose to enrol in public or private universities. Statistics show that, in 2016, a total of 20,232 students were enrolled in community college and declined by $10 \%$ in 2018 (Wan et al., 2018).

Generally, community colleges in Malaysia are facing a declining number of students' enrolment due to the increased number of public and private higher education institutions. In addition, prospective students have more privileges to enter public universities because there are many study loans and scholarship offered for them. Due to these issues, the 
competitions between all these education institutions are very fierce day by day. Therefore, the main problem that would be focused in this study is the brand awareness. The college has inadequate marketing strategies to bring out its strengths and uniqueness to the public, which in turn, lead to low brand image and brand awareness.

\section{Literature Review}

\section{Advertising and Promotion}

Marketing develops communications to create awareness of products and services and generate interest in business offerings to customers (Hsu \& Chen, 2018). The use of marketing communication tools comprehensively is a necessary strategy for every marketer (Šerić, 2017). Many firms adopt various promotional tools such as advertising, public relations, online communication and direct marketing to create their respective distinct images (Momen et al., 2019). Now, firms are using various promotional tools to position their brand in the market and at the same time attract customers to purchase their offerings. Therefore, promotional tools are important to all firms to create awareness and brand image to the target customers.

In recent years, the wide usage of internet all around the world has changed the way advertising delivers its messages. According to Belanche et al (2019), the digital platforms involving browsers, webpages and social media advertising have faded out the role of television, radio and newspapers in advertising. Unlike conventional advertising, online advertising enables companies to reach their target public more affordably and efficiently than ever (Lin \& Fu, 2018). Lin and Fu (2018) then added, however, designing an effective online advertising copy to attract the attention of the target audience remains a major challenge for marketers. Marketers need to understand the real value of the products offered to the customers so that it will be easier for them to design an effective online advertising to really capture the target audiences.

Malaysian higher education sector consists of more than 50 universities and 20 university colleges, over 400 private colleges and eight foreign branch campuses (Momen et al., 2019). Momen et al (2019) also added that these institutions are competing for the same group of local and regional students. Nowadays, promotional tools through online are very crucial in communicating with the prospective students out there as they are also seeking information about their future enrolments.

\section{Social Media Marketing}

Digital marketing is an adaptive, technology-enabled process by which firms collaborate with customers and partners to jointly create, communicate, deliver, and sustain value for all stakeholders (Kannan \& Alice, 2017). There are many digital marketing strategies which are search engine optimization (SEO), search engine marketing (SEM), email marketing, content marketing, influencer marketing, campaign marketing, content automation, social media optimization and social media marketing. In this study, social media marketing was used and implemented in the intervention to improve the problem diagnosed.

Social media applications nowadays have increasingly become an important part of people's daily life and they are more likely to move their interactions to the virtual platforms (i.e. Facebook, Instagram, LinkedIn and Twitter) (Alalwan et al. 2017). This shows that social media 
would be an efficient marketing tool as people are considering social media as a part of their daily life. As stated by Alalwan et al. (2017), social media has become influential implications that have been progressively engaged in most aspects of people's lives (i.e. social life, commercial life, business life, educational sector, political life). People going through social media in their daily life, mainly for social life engagement but at the same time, there are more than social life engagement that they are looking for such as shops, ideas, inspirations and many more.

Alalwan et al (2017) highlighted that social media gives big impact towards firms' marketing goals and strategy because it could enhance two-way communication between customers and the brands, at the same time build the brand identity to the broader audiences. Social media marketing could be defined as "a dialogue often triggered by consumers/audiences, or a business/product/service that circulate amongst the stated parties to set in motion a revealing communication on some promotional information so that it allows learning from one another's use and experiences, eventually benefitting all of the involved parties."

Social media marketing would be very effective if the audiences who come across the media posted start to engage with it such as share, like and comment. Social media engagement can be defined as consumer engagement behaviour with social media marketing content, including brand-generated and peer-generated content, on social media platforms such as Facebook and YouTube (Cao et al., 2020). Cao et al (2020) then added that social media engagement consists of consumption behaviour; that represents a minimum level of engagement that users passively consume the social media marketing content such as read and watch the content, contribution behaviour; requires a higher level of engagement involving peer-to-peer and peer-to-content interactions such as commenting on the marketing post, and creation behaviour; the highest level of engagement where consumergenerated content is published in social media.

A few studies show that social media engagement behaviour are varies depending on the social media applications such as Instagram and Twitter (Guidry et al., 2017), Facebook (Wang et al., 2017) and YouTube. Social media marketers need to understand the attributes and uniqueness of each social media platform to get a better engagement behaviour from their target audiences. Social media platforms are increasingly becoming part of people activities for social interaction, information, news, and entertainment. Hence, the use of social media platform for businesses will help the firms to deliver marketing messages to the audiences and the effectiveness will become better if the marketers understand the specific social media attributes and how the consumers engage in a different social media platform.

\section{Brand Awareness}

According to Sharifi (2014), brand awareness is the attribute that generates customers' recognition of a brand. Foroudi (2019) stated that brand awareness consists of defining and generating the familiarity and recognizability of a target audience towards a brand. A brand that a certain company wants to introduce must be impactful so that it can be easily recalled and recognized. Consumers familiarity with a name and logo tend to trust the company's products and services (Foroudi, 2019). There are plenty of strategies that can be used by marketers to build and increase brand awareness. 
In recent years, the increasing trend of using social media platforms by everyone all around the world has changed the way companies to reach out to their target audiences. Godey et al. (2016) found that the quickly expanding marketing channel, which is social media platforms has brought out opportunities for companies to build brand awareness because the channel already reach two billion internet users. Social media is one of the trending channels that is widely used by businesses to build brand awareness and eventually influence customers' purchase intention. Even though social media is the trending platform to build brand awareness, marketers need to publish a high-quality content that can capture consumers' attention. Dabbous and Barakat (2020) indicated that the quality of content published by firms on social media could influence users' brand awareness and help them easily recall and recognize the brand.

\section{Research Framework}

Figure 1 shows the research framework that the study used to improve the college's Instagram for increased brand awareness as well as engagement intention and behaviour.

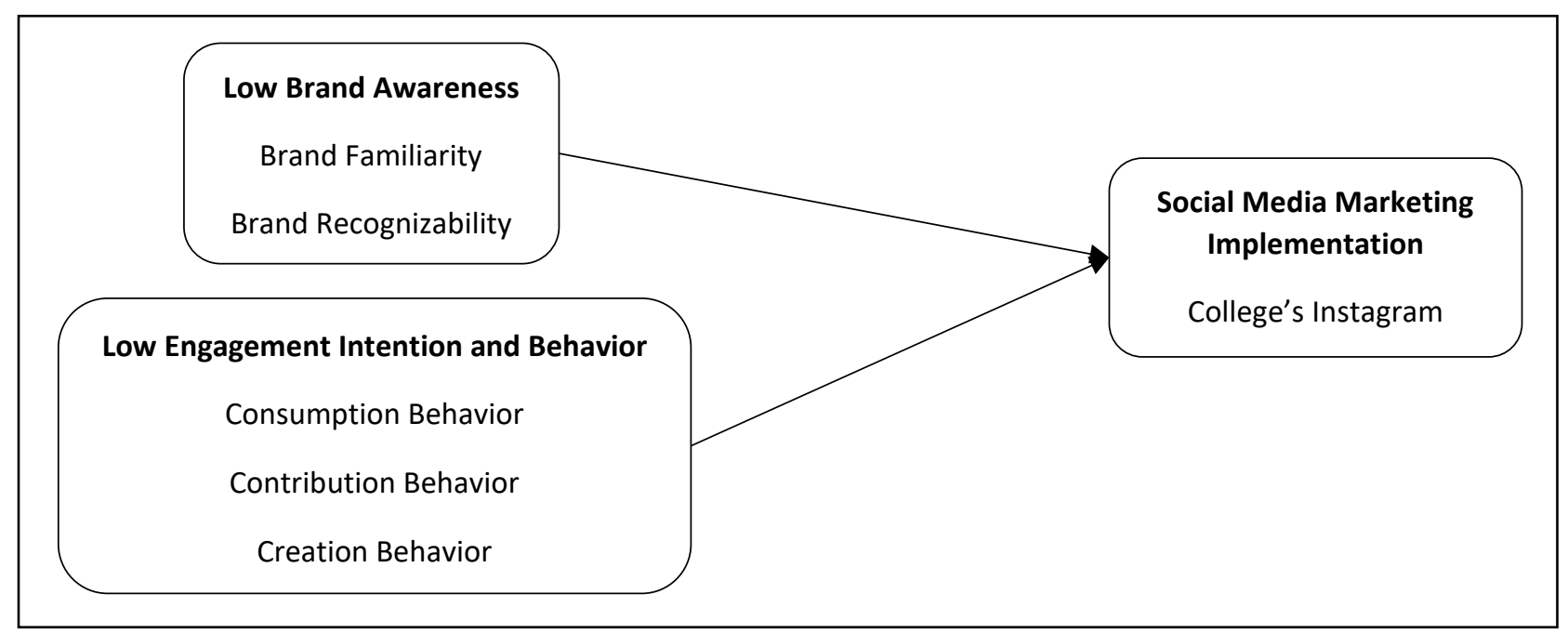

Figure 1: Research Framework

\section{Research Methodology}

\section{Action Research Process Model}

There are three stages used in the intervention: input, transformation and output. Based on the action research process model as proposed by Johnson (1976), the action research process model of this study is constructed in Figure 2. 


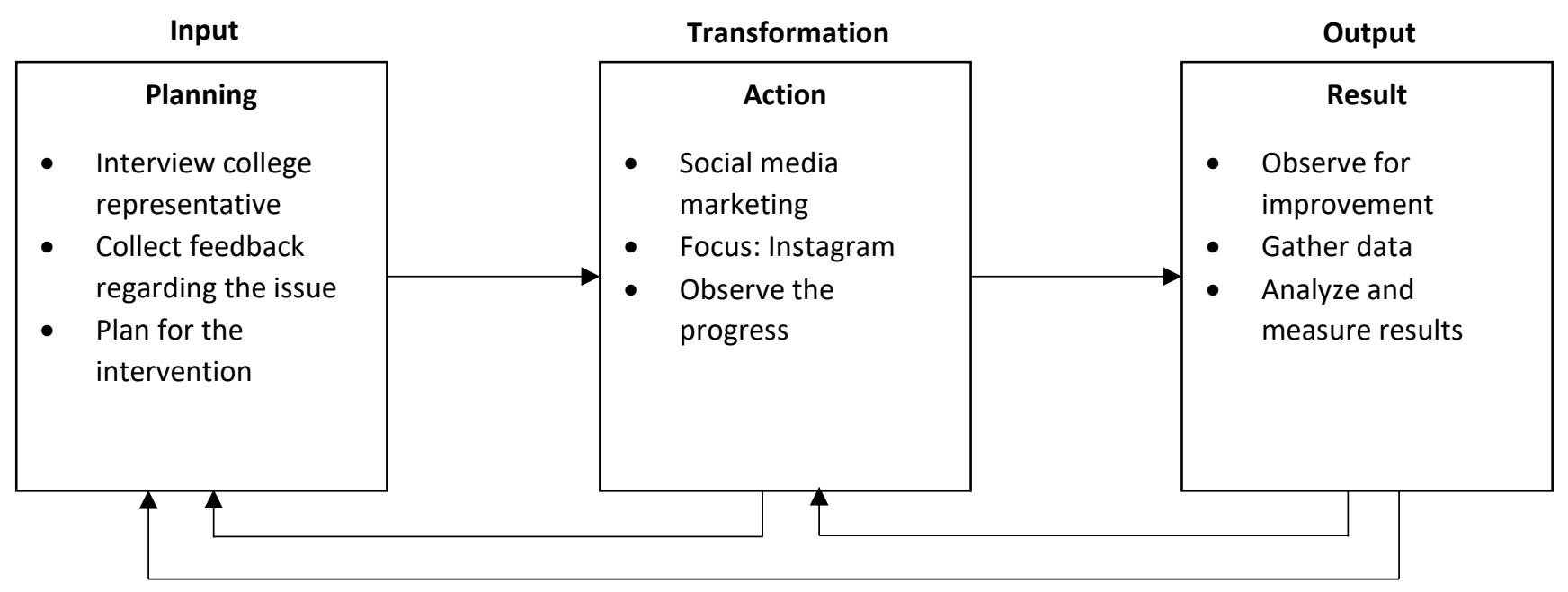

Figure 2: Action Research Process Model for the Private College

\section{Research Design}

In overall, the study had two cycles which are cycle 1 and cycle 2 . As referred to Kemmis et al. (2014), the Figure 3 shows the flow of the action research cycle 1 and cycle 2:

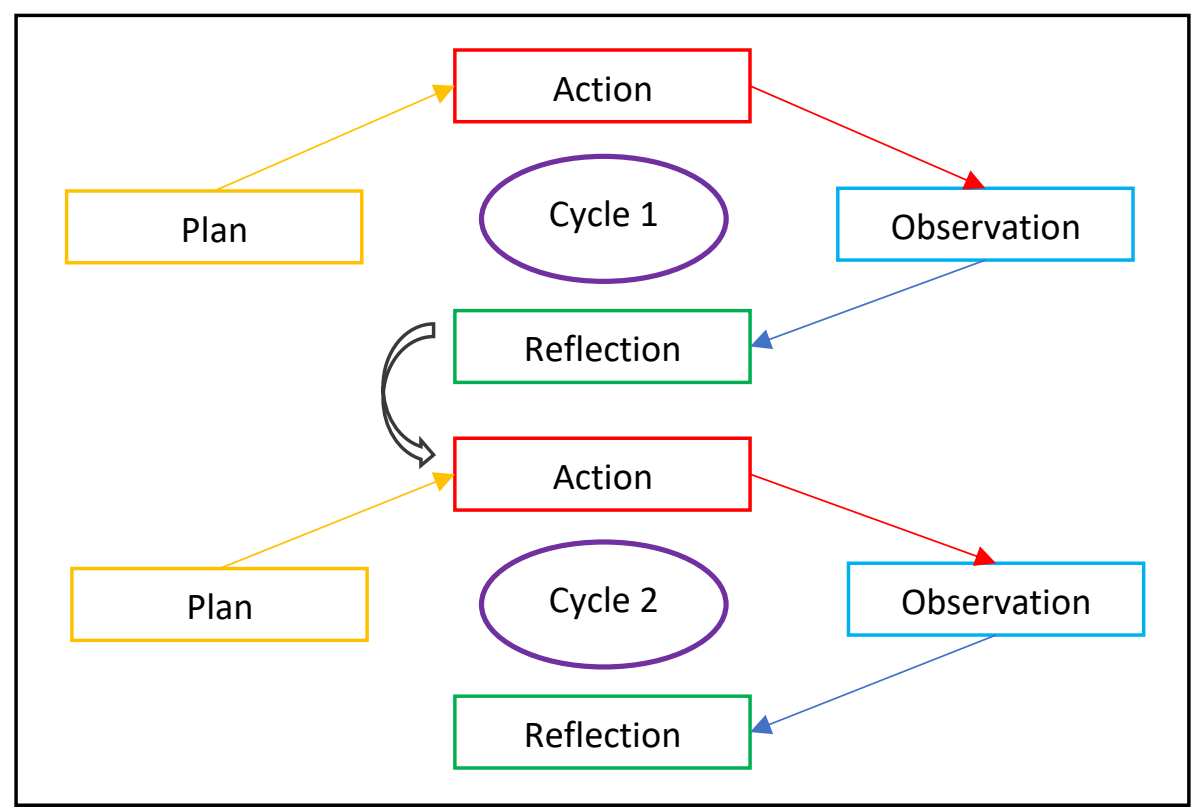

Figure 3: Flow of Action Research

\section{Cycle 1 of Research}

In this study, the plan is to increase brand awareness through social media marketing. To make the plan successful, the action taken was to implement the social media marketing strategies using the college Instagram account. The Instagram manager must improve the content consistency, utilize the usage of hashtags and start advertising the Instagram post through Instagram ads feature. The results then observed to judge whether the objective was achieved or not. After the observation, the researcher started to conduct reflections on the findings for cycle 1. 


\section{Cycle 2 of Research}

After the feedbacks and reflections in Cycle 1, the researcher would review further to resolve the problematic situation of the research. Cycle 2 is basically repeating the process in Cycle 1 with modifications in the action part so that the problematic situation is resolved. The observation of Cycle 2 is also different from Cycle 1 because there must be a new data gathering to have a better and improved feedbacks from Cycle 1.

\section{Research Instruments}

There are two types of data collection methods which are qualitative and quantitative methods. For the research instrument, there were three instruments used to collect the data which included interview, questionnaire and Instagram insights. Table 1 is the summary of the research instruments used in this research.

Table 1: Summary of Research Instruments

\begin{tabular}{|llcc|}
\hline Research Question & Approach & Software & Analysis \\
\hline $\begin{array}{l}\text { What are the challenges faced } \\
\text { by the private college? }\end{array}$ & Qualitative & - & Coding \\
$\begin{array}{l}\text { What is the marketing strategy } \\
\text { needed to improve the college }\end{array}$ & Quantitative & SPSS & Descriptive Analysis \\
$\begin{array}{l}\text { brand awareness? } \\
\text { How effective is the marketing } \\
\text { strategy implemented to solve } \\
\text { the problem faced by the } \\
\text { private college? }\end{array}$ & Quantitative & $\begin{array}{c}\text { Instagram } \\
\text { analytics }\end{array}$ & $\begin{array}{c}\text { Follower growth, } \\
\text { impressions, reach, } \\
\text { profile visits }\end{array}$ \\
\hline
\end{tabular}

\section{Data Analysis}

\section{Cycle 1}

The founder of the private college was interviewed and he highlighted that there are several challenges faced by the college. All the challenges were then categorized into two themes which are brand awareness and management strategy. From the finding, it can be concluded that brand awareness is repeatedly being mentioned by the college representative during the interview session. This shows that brand awareness is the biggest challenge faced by the college now. Table 2 shows the categories of the challenges based on themes. 
Table 2: Categories of Challenges in the Private College

\begin{tabular}{|c|c|}
\hline THEME 1: BRAND AWARENESS & Analysis \\
\hline $\begin{array}{l}\text { Bring the mission and message of the college out to the } \\
\text { public }\end{array}$ & CHALLENGE 3 \\
\hline $\begin{array}{l}\text { To communicate with the public about the college } \\
\text { offerings }\end{array}$ & CHALLENGE 4 \\
\hline Bring the brand to the public & CHALLENGE 5 \\
\hline To increase brand exposure & CHALLENGE 6 \\
\hline $\begin{array}{l}\text { People only realized the message that the college trying } \\
\text { to deliver once they entered/enrolled to the college } \\
\text { program }\end{array}$ & CHALLENGE 7 \\
\hline $\begin{array}{l}\text { Tried FB ads - spent thousands of ringgits but get no } \\
\text { positive response }\end{array}$ & CHALLENGE 8 \\
\hline $\begin{array}{l}\text { Tried Instagram as one of the platforms to deliver } \\
\text { message but not that effective }\end{array}$ & CHALLENGE 9 \\
\hline $\begin{array}{l}\text { Have enrolment issue due to lack of brand awareness } \\
\text { but enrolment is not the biggest issue }\end{array}$ & CHALLENGE 10 \\
\hline $\begin{array}{l}\text { Messages are delivered only through WOM of students, } \\
\text { alumni and parents }\end{array}$ & CHALLENGE 11 \\
\hline \multicolumn{2}{|l|}{ THEME 2: MANAGEMENT STRATEGY } \\
\hline To get the right certificates from recognizable party & CHALLENGE 1 \\
\hline $\begin{array}{l}\text { To decide on the courses/programs that are useful to } \\
\text { meet the industrial needs }\end{array}$ & CHALLENGE 2 \\
\hline
\end{tabular}

Two surveys were conducted to validate the problem and would be used to decide the suitable marketing strategy to be implemented in the study. The survey of brand awareness was conducted to find out the public brand awareness towards the college. The survey was mostly answered by female, at the age between 21 to 25, Malay, bachelor's degree holder, single and income of RM1500 and below. There were only one Indian and 6 Chinese who answered the survey. Two persons with certificates and doctoral degree had answered the survey while there were three persons at the age of below 20 answered the survey. From the demographic analysis, the survey was not well distributed to the public because most of the respondents who answered the survey were Malay and fresh graduates or students because most of them were at the age of 21 to 25 with the income of RM1500 and below. Table 3 indicates the descriptive statistics for brand awareness variables.

Table 3: Descriptive Statistics for the Brand Awareness Variables

\begin{tabular}{|lcccc|}
\hline Variable & N & $\begin{array}{c}\text { Standard } \\
\text { deviation }\end{array}$ & Mean & Level of mean score \\
\hline Brand familiarity & 121 & 0.8562 & 2.0661 & Low \\
Brand & 121 & 0.8858 & 2.2149 & Low \\
recognizability & & & & \\
\hline
\end{tabular}

The survey of engagement intention and behavior was conducted to find out the followers of the college's Instagram account engagement intention and behavior towards its Instagram activities. The followers of the Instagram account who answered the survey were only 12 out 
of 71 before the implementation of social media marketing. This shows that the response rate of the survey was only $16.9 \%$. From the demographic analysis, $50 \%$ of them were male and another $50 \%$ were female. From 12 of the respondents, only two groups of age answered the survey who were below 20 and 21 to 25 groups but only two of them were from the age of 20 and below while another 10 who aged between 21 to 25 years old. One out of 12 spent less than one hour per day on social media. The respondents of this survey were from three locations in Malaysia which are Kuala Lumpur, Putrajaya and Pulau Pinang. Table 4 explains the descriptive score for the variables involved in this survey.

Table 4: Descriptive Statistics for the Engagement Intention and Behavior Variables

\begin{tabular}{|lcccc|}
\hline Variable & $\mathbf{N}$ & $\begin{array}{c}\text { Standard } \\
\text { deviation }\end{array}$ & Mean & $\begin{array}{c}\text { Level of mean } \\
\text { score }\end{array}$ \\
\hline $\begin{array}{l}\text { Engagement } \\
\text { intention }\end{array}$ & 12 & 0.6215 & 4.0000 & High \\
$\begin{array}{l}\text { Consumption } \\
\text { behaviour } \\
\begin{array}{l}\text { Contribution } \\
\text { behaviour }\end{array}\end{array}$ & 12 & 0.7496 & 3.4792 & Average \\
Creation behaviour & 12 & 0.63812 & 2.2917 & Low \\
\hline
\end{tabular}

The implementation of social media marketing was conducted with the aim to grow the brand. The followers' growth, impressions, reach and profile visits were observed before and after the implementation using an Instagram Analytics tool. The intervention was initiated from 1st August 2020 until 12th August 2020. Therefore, all the data were observed starting from 30th July 2020 to see the improvements from the intervention. The college's Instagram profile was able to get the highest impressions on 10th August 2020. The college started a campaign promotion from 8th August 2020 until 11th August 2020, that is why the number of impressions from 8th to 11th August 2020 was the highest as compared to the other days. Even though no promotions for the other days, the college still managed to get a quite high number of impressions as compared to 30th of July 2020. This is because the college used hashtags for its latest post to reach a bigger audience group.

Reach is the number of unique accounts has seen the content posted by the college. The highest reach that the college acquired was on 10th August 2020. This is because on 8th August until 11th August 2020, this private college started a promotion campaign through Instagram ads feature. The campaign successfully reached thousands of unique Instagram users. In addition, starting from 1st August until 12th August, the numbers of reach for all the posts were high as compared with before the intervention being done. Starting on 1st August 2020 , the visits to the Instagram profile started to grow and it had the highest profile visit on 10th August 2020. The Instagram achieved a high number of profile visits because of the ongoing Instagram ads promotion that started from 8th August 2020 until 11th August 2020. During no promotion period, the college's Instagram account could acquire a few profile visits due to the use of hashtags in their postings. A total of 57 followers gained during the intervention period starting from 1st August until 12th August 2020. The overall followers' growth rate from the start of the intervention until 12th August 2020 was $80.3 \%$ as before 1 st August 2020, the followers of the Instagram was 71 and after all the posts and the promotions 
made, the followers increased to 128 . The number of followers increased sharply on 10th August 2020 when the promotion period was in place.

\section{Reflection and Discussion of Cycle 1}

Brand awareness is a major problem especially for a new higher education institution like this private college. To cope with this challenge, the college needs to have a very good marketing strategy at the same time it needs to invest some amount of money for advertising and promotions. Once the brand awareness problem is solved, the college will become a big institution that can offer good quality of programs and courses to meet industrial demands nowadays. From the survey of the brand awareness, the result shows that the public have limited knowledge about this college. The variables included in the survey are brand familiarity and brand recognizability. After analysing the mean of both variables, the result shows that the level of mean score for both variables are low. This means that public never heard of the brand name or even seen it anywhere because they are not familiar with the brand and do not recognize it.

In addition, the survey of the Instagram engagement intention and behaviour was conducted to investigate the current Instagram followers' behaviour towards the college Instagram activities. From the analysis, the researcher found out that the followers had intention to engage with its Instagram account because its mean score is high but their behaviour towards the college Instagram contents showed low engagement. According to Dabbous and Barakat (2020), brand awareness is the one of the outcomes of social media engagement. Once the social media has a very good followers engagement performance, it will be easier for the brand to build its brand awareness through social media. Hence, from the outcome of these two surveys conducted, it can be concluded that this private college needs to have a better followers engagement behaviour to increase its brand awareness through social media marketing and engagement behaviour because the followers have the intention to engage but the content is less engaging for them to follow.

The marketing strategy implemented is social media marketing which is one of the digital marketing strategies. The implementation was conducted by posting a better content design and using hashtags to reach a wider audience. Moreover, the college also did promotions through Instagram ads. Overall, the impressions, reach, profile visits and followers' growth had showed positive changes towards the performance of this private college Instagram account. The use of social media which can reach over two billion internet users (Godey et al., 2016) can build the brand awareness to the public easily with a well-planned social media marketing strategy. From the finding of the Instagram performance, it can be determined that the marketing strategy implemented is effective as the Instagram was able to increase its followers by $80.3 \%$ during the implementation period. Finally, social media marketing must be consistently implemented and monitored to gain more brand exposure over time.

\section{Recommendation for Cycle 2}

There are so much more to improve in the next phase of implementation. In the previous intervention, the implementation period was very short as it was about twelve days only. In the next phase, a longer period of implementation needed to be planned so that a bigger insight of the social media performance can be observed and analyzed. Secondly, the social media manager of the college can thoroughly plan a more organized content and more videos 
such as the courses offered, the learning environment and the fieldwork activities involved by the students should be added as a part of the contents so that the profile feeds will become more attractive and engaging. The firms that wish to communicate an emotional and long message to achieve an active engagement should utilize videos in their content (Shahbaznezhad et al., 2021). Shahbaznezhad et al. (2021) then added that social media posts with richer content (e.g., videos) are more effective in social media communication compared to lower rich content (e.g., photos), and therefore will facilitate behaviors that reflect greater engagement in the form of active engagement behavior.

In addition, the contents must be consistently posted so that people who are about to recognize the brand will often come across with the brand and at the end of the day, they will remember the brand as one of the colleges in Selangor that provides a very good study experience. Furthermore, a further research related to the suitable hashtags to be used in the post need to be conducted, This is because hashtag is one of the ways that the brand can reach a broader audience without spending any money but it needs a detail research to choose the best hashtags that are discoverable by the right audiences.

\section{Cycle 2}

In cycle 2, the improvements of the intervention are a longer period of intervention and the various types of contents posted where the college Instagram account manager also posted some videos to improve the followers' engagement behavior towards its Instagram activities. At the beginning of cycle 1, a survey about the college Instagram followers' engagement behavior towards its Instagram activities was distributed among the followers. A total of 12 respondents had completed the survey. At the end of cycle 2 intervention period, the same questionnaires were distributed to the same respondents to collect their feedbacks on their engagement behavior towards the college Instagram activities after some content's improvements are made.

In this cycle, the researcher put emphasis on the followers' engagement behavior. Therefore, the likes, comments, shares and saved posts were observed to find out whether the followers of the Instagram account were engaged to the contents posted or not. The followers' engagements helped the posts to reach a broader audience, hence they would also help in improving the college brand awareness to the people who were not following its Instagram account. At the same time, the college Instagram manager still used a lot of hashtags in their posts to reach broader audience and continuously promoted some posts so that the name of the college would become familiar to the public.

The values of mean are used to analyze the items in the questionnaire distributed in cycle 2 . The level of mean score for each variable before and after the intervention were compared to observe the change of means for both sets of questionnaires. The Table 5 below shows the comparison of the mean scores for the followers' engagement behavior before and after the intervention. 
Table 5: Comparison of the Level of Mean Score Before and After the Intervention

\begin{tabular}{|c|l|c|c|c|c|c|}
\cline { 3 - 6 } No. & \multicolumn{1}{|c|}{ Variable } & $\mathrm{N}$ & Mean & $\begin{array}{c}\text { Level of mean } \\
\text { score }\end{array}$ & Mean & $\begin{array}{c}\text { Level of mean } \\
\text { score }\end{array}$ \\
\hline 1. & $\begin{array}{l}\text { Consumption } \\
\text { behavior }\end{array}$ & 12 & 3.4792 & Average & 4.2500 & High \\
\hline 2. & $\begin{array}{l}\text { Contribution } \\
\text { behavior }\end{array}$ & 12 & 2.2917 & Low & 4.1458 & High \\
\hline 3. & Creation behavior & 12 & 2.1389 & Low & 2.5625 & Average \\
\hline
\end{tabular}

From the Table 5, it shows that there are changes of the mean score level for all the three variables of the college Instagram followers' engagement behavior. Before the intervention, the followers' consumption behavior was average and after the intervention, they had high level of consumption behavior. This shows that the followers were more motivated to watch and read the contents of the college Instagram. Their contribution behavior before the intervention was low with the mean of 2.2917 only and at the end of the intervention period, their level of mean score became high with the mean of 4.1458. From this change, it can be concluded that the followers were engaging well with the college Instagram contents by commenting, liking and share the contents to the public. The creation behavior required the highest commitment of engagement where the contents for this behavior is user-generated such as photos at the college, videos and reviews about the college. Therefore, the level of mean score of this engagement behavior for before intervention is low and after intervention is average which means that the followers had average engagement behavior.

A nonparametric Wilcoxon signed-ranks test was conducted to compare the difference of the result for before and after the intervention. The data used for this test was collected from the followers' engagement behavior questionnaire that were distributed to the college Instagram followers before and after the intervention. Table 6 shows the summary of analysis after the intervention.

Table 6: Summary of analysis after the Intervention

\begin{tabular}{|c|c|c|}
\hline Condition & \multicolumn{1}{|c|}{ Finding } & Result \\
\hline P-value $<0.05$ & $0.003<0.050$ & Significant \\
\hline $\begin{array}{c}\text { Calculation value }< \\
\text { critical value }\end{array}$ & $1.00<14^{*}$ & Significant \\
\hline $\begin{array}{l}\text { Both conditions resulted significant. Therefore, it can be concluded that there is } \\
\text { difference between before and after. } \\
\text { *The critical value for } \mathrm{N}=12 \text { is } 14 .\end{array}$ \\
\hline
\end{tabular}

The effectiveness of the marketing strategy implemented was measured using the Instagram insights to see its performance throughout the intervention period. For cycle 2, the insights observed were compared between the photos and videos posted to see the engagement of each post. As cycle 2 added videos as a part of the contents posted in the Instagram feeds, the engagements of the videos were then observed to see the reach, impression, views, comments and shares of the post. The videos were posted alternately with the photos as the feed contents. 
From the Instagram engagement, it could be observed that the followers were more attracted to like, comment and share on the videos. The photo posted on 14th November had one share which was a good achievement for a photo post. The most important followers' engagement activity that needed to be observed to increase the brand awareness of the college was the number of shares. This is because, once the followers shared the contents in their personal Instagram account, their followers who did not follow the Instagram account would come across with the content and it would eventually improve the college's brand awareness.

One of the videos posted that were related to the courses offered in the college had the highest number of shares which was 21 shares as compared to all the other posts. This is such a good achievement as the followers of the Instagram were interested with the content of the video and they wanted other people to know about the courses offered by the college too, hence they decided to share the video in their personal Instagram account. The other videos posted also had a few numbers of shares. From the numbers of shares, it can be concluded that followers of the college Instagram were more interested to engage with the video content posted. Thus, the manager of the college Instagram needed to post different feeds content to get a richer followers' engagement.

The photos and videos posts were compared to observe their reach, impression and profile visits. From the comparison, the photos and videos had a high number of reach and impression while videos had a higher number of profile visits. Overall, the Instagram manager was required to post variety types of contents to engage the users. This is because there are some people who are attracted to watch videos while there are some people who are more attracted to engage with photo contents. Therefore, a variety of contents is important to attract followers to engage with the content posted.

\section{Reflection and Discussion of Cycle 2}

The intervention in the second cycle only focused on the followers' engagement behavior where the researcher only observed the change of the followers' engagement behavior. The engagement observed included views, likes, comments and shares. The observation of views and likes of the posts could be misleading as the Instagram started counting the view once the video started to play even though the followers were not watching the video to the end, and for likes, the followers could simply like the posts without really understand the content of the posts. On the other hand, the posts shares showed that the followers were sharing some useful information to their followers who were not following the Instagram account so that more people would aware about this college. It can be concluded that, the followers were really viewing the contents of the posts to make them share it with the others.

The biggest challenge of this private college was to communicate with the public to deliver the college's message. This is due to its low brand awareness among its target audiences. Therefore, the researcher should distribute the brand awareness questionnaire at the end of the intervention period to accurately measure the impact of social media marketing and engagement behavior implementation towards this college brand awareness. Due to the time constraints, the researcher and the manager of the Instagram account decided to just observe the performance of the Instagram at the end of the intervention and if the performance of the Instagram account has shown improvements, it can be concluded that the college brand awareness was improved. 


\section{Conclusion}

This private college's major challenge is less brand communication to the public because this college has a very poor brand awareness. Therefore, this study was conducted to implement social media marketing and investigate engagement behavior with aim to increase the college's brand awareness. There are three objectives of this study; to find out the challenges faced by the private college, to implement marketing strategy to improve public's brand awareness towards the college and to measure the effectiveness of the implemented marketing strategy to solve the problem of the college. The social media used in the study was Instagram and the marketing activities included engaging content creations, IG ads campaign and the use of hashtags.

This study consisted of cycle 1 and cycle 2 interventions and there were positive impacts derived from both cycles of interventions. Cycle 1 was used to approach the public while cycle 2 was aimed to improve the Instagram followers' engagement behavior. From the findings of the study, there were positive improvements towards the performance of the college Instagram. These improvements showed that the college was striving to a better brand awareness among the publics. Therefore, all the mentioned objectives were successfully achieved by the researcher at the end of this study.

Finally, the study can contribute to the education industry by providing them better insights on how they should manage their social medial and utilize the benefits of social media in this rapid technological advancement era where most of the people now are using social media for communication and discovery of new brands. The findings of the study could enlighten marketers to use creative, appealing and interactive contents to engage consumers to disseminate positive word-of-mouth in their social media community. Furthermore, there are limited studies about the action research in higher education institutions, therefore, this study can be served as a guideline for future researchers.

\section{References}

Alalwan, A. A., Rana, N. P., Dwivedi, Y. K., \& Algharabat, R. (2017). Social media in marketing: A review and analysis of the existing literature. Telematics and Informatics, 34(7), 1177-1190.

Belanche, D., Cenjor, I., \& Pérez-Rueda, A. (2019). Instagram Stories versus Facebook wall: An advertising effectiveness analysis. Spanish Journal of Marketing, 23(1), 69-94.

Cao, D., Meadows, M., Wong, D., \& Xia, S. (2020). Understanding consumers' social media engagement

behaviour: An examination of the moderation effect of social media context. Journal of Business Research, 1-12.

Dabbous, A., \& Barakat, K. A. (2020). Bridging the online offline gap: Assessing the impact of brands' social network content quality on brand awareness and purchase intention. Journal of Retailing and Consumer Services, 53, 101966.

Foroudi, P. (2019). Influence of brand signature, brand awareness, brand attitude, brand reputation on hotel industry's brand performance. International Journal of Hospitality Management, 76, 271-285.

Godey, B., Manthiou, A., Pederzoli, D., Rokka, J., Aiello, G., Donvito, R., \& Singh, R. (2016). Social media marketing efforts of luxury brands: Influence on brand 
equity and consumer behavior. Journal of Business Research, 69(12), 58335841.

Guidry, J. P. D., Jin, Y., Orr, C. A., Messner, M., \& Meganck, S. (2017). Ebola on Instagram and Twitter: How health organizations address the health crisis in their social media engagement. Public Relations Review, 43(3), 477-486.

Hsu, C. L., \& Chen, M. C. (2018). How gamification marketing activities motivate desirable consumer behaviors: Focusing on the role of brand love. Computers in Human Behavior, 88, 121-133.

Johnson, R. A. (1976). Management, systems, and society: An introduction. Pacific Palisades, Calif.: Goodyear Pub. Co.

Kannan, P. K., \& Alice, H. (2017). Digital marketing: A framework, review and research agenda. International Journal of Research in Marketing, 34(1), 22-45.

Kemmis, S., McTaggart, R., \& Nixon, R. (2014). The action research planner. Doing critical participatory action research. Springer.

Lin, C. F., \& Fu, C. S. (2018). Evaluating online advertising effect: An approach integrating means-end conceptualization and similarity analysis. Electronic Commerce Research and Applications. 32, 1-12.

Momen, M. A., Sultana, S., \& Haque, A. K. M. A. (2019). Web-based marketing communication to develop brand image and brand equity of higher educational institutions: A structural equation modelling approach. Global Knowledge, Memory and Communication, 69(3), 151-169.

Šerić, M., Ozretić-Došen, Đ., \& Škare, V. (2020). How can perceived consistency in marketing communications influence customer-brand relationship outcomes? European Management Journal, 38(2), 335-343.

Shahbaznezhad, H., Dolan, R., \& Rashidirad, M. (2021). The role of social media content format and platform in users' engagement behavior. Journal of Interactive Marketing, $53,47-65$.

Sharifi, S. S. (2014). Impacts of the trilogy of emotion on future purchase intentions in products of high involvement under the mediating role of brand awareness. European Business Review, 26(1), 43-63.

Wan, C. Da, Sirat, M., \& Razak, D. A. (2018). Education in Malaysia towards a developed nation. Retrieved from https://www.iseas.edu.sg/images/pdf/ISEASEWP2018-4Wan.pdf

Wang, R., Kim, J., Xiao, A., \& Jung, Y. J. (2017). Networked narratives on Humans of New York: A content analysis of social media engagement on Facebook. Computers in Human Behavior, 66, 149-153. 